Biochimica et Biophysica Acta, 582 (1979) 412-422

(C) Elsevier/North-Holland Biomedical Press

BBA 28802

\title{
DESTRUCTION AND RESYNTHESIS OF MOUSE $\beta$-GLUCOSIDASES
}

\author{
ATSUSHI HARA and NORMAN S. RADIN
}

Mental Health Research Institute (Department of Psychiatry) and Department of Biological Chemistry, University of Michigan, Ann Arbor, MI 48109 (U.S.A.)

(Received July 3rd, 1978)

Key words: Glucosidase turnover; Phenylhydrazine injection; Glucocerebrosidase; Arylglucosidase; Protein turnover; (Mouse)

\section{Summary}

1. Injection of a single dose of conduritol B epoxide into mice produced almost complete destruction of glucocerebrosidase (D-glucosyl- $N$-acylsphingosine glucohydrolase, EC 3.2.1.45) in liver, spleen, brain, and kidney within $5 \mathrm{~h}$. Restoration of activity became noticeable within 1 day ( 2 days in the case of brain) and was about $80 \%$ of normal within 16 days.

2 . The same injection produced less destruction of aryl $\beta$-glucosidase (EC 3.2.1.21), measured at $\mathrm{pH} 5.4$ with methylumbelliferyl glucoside in the absence of taurocholate. Brain showed the least amount of destruction, about $50 \%$, but measurements of activity at lower $\mathrm{pH}$ values revealed complete loss of activity. This suggests that brain contains two different aryl glucosidases with differing sensitivity to the inhibitor. Liver, on the other hand, did not show differential destruction when assayed at different $\mathrm{pH}$ values. Resynthesis of the enzyme activities was almost complete by 16 days.

3 . Injection of phenylhydrazine produced hemolysis and spleen enlargement, with concomitant increases in specific activities of glucocerebrosidase and aryl glucosidase in liver and spleen (but not in kidney). When this experiment was done in mice previously treated with conduritol $\mathrm{B}$ epoxide, the reappearance of cerebrosidase was found to be accelerated. This is interpreted to mean that the increased load of glucolipids from the erythrocytes had induced an enhanced synthesis of the glucohydrolase. A similar explanation may apply to aryl glucosidase and glucopeptides in the cells.

\section{Introduction}

If an irreversible inhibitor of an enzyme is injected into an animal, and if the concentration of the inhibitor is sufficient to destroy most of the animal's enzyme, one can follow the rate of reappearance of the enzyme and thereby 
obtain an idea as to the turnover rate of the enzyme. This approach was used by Price et al. [1] with liver catalase and by Davis and Agranoff [2] with retinal acetylcholinesterase. Both enzymes showed a zero order rate of regeneration, from which the conclusion was drawn that enzyme molecules normally undergo degradation on a random basis according to the general concept of turnover.

This report describes a similar application to $\beta$-glucosidases of mice, based on the observation by Legler $[3,4]$ that plant glucosidases react covalently with conduritol B epoxide to form an enzymatically inert product. The observation was extended by Kanfer et al. [5,6] by injecting young mice with the epoxide on a daily basis for 3 or 4 weeks. The $\beta$-glucosidase activities in various tissues, measured with glucocerebroside (glucosyl ceramide) and with methylumbelliferyl- $\beta$-D-glucoside as substrates, were markedly decreased as the result of the treatment, while several other acid glycosidases were somewhat less affected. It seemed likely to us that the inhibitor actually destroyed the enzymes quite quickly and that the excess compound was rapidly excreted, thus making it possible to follow the resvnthesis of the enzymes.

We also applied the approach to the question: if one induces an increased level of tissue glucosidase, is the increase due to faster synthesis or to slower degradation of the enzyme? Kampine et al. [7] found that the rapid destruction of rat erythrocytes by phenylhydrazine injection resulted in a large increase in the specific activity of glucosidase of the spleen. By injecting conduritol $\mathrm{B}$ epoxide into animals it should be possible to see whether or not the rate of enzyme regeneration is enhanced by the loading phenomenon. Some of the findings have been reported orally [8].

\section{Materials and Methods}

\section{Reagents}

The inhibitor was synthesized by a slight modification of the methods of Legler [3] and Nagabhushan [9]. Conduritol B (tetrahydroxycyclohexene, 400 $\mathrm{mg}$ ) was epoxidized with $724 \mathrm{mg}$ of $m$-chloroperoxybenzoic acid (85\% pure, Aldrich Chemical Co., Milwaukee, WI) in $60 \mathrm{ml}$ of methanol. After 4 days the solvent was removed under vacuum and the chloro-compounds were removed with 3 times $40 \mathrm{ml}$ of ether. The residue was dissolved in $95 \%$ ethanol, the solution was concentrated under vacuum until crystals appeared, and the mixture was allowed to crystallize at $-20^{\circ} \mathrm{C}$. The m.p. was $159-161^{\circ} \mathrm{C}$ (Legler's value: $157-159^{\circ} \mathrm{C}$ ). Thin-layer chromatography of the epoxide on silica gel with chloroform $/$ methanol/water $(60: 35: 8, \mathrm{v} / \mathrm{v})$ yielded a single spot with $R_{\mathrm{F}}=0.32$, the same as that of conduritol $B$. Only the epoxide reacted with a spray for epoxides [10]. Both compounds could be visualized by spraying with dichromate/sulfuric acid and heating.

A further test of purity was carried out by brominating the double bond in conduritol B. The sample was dissolved in methanol and treated with a slight excess of bromine in methanol for a few minutes. The product was freed of liquid with a stream of nitrogen and found to yield a spot with $R_{\mathrm{F}}$ of 0.56 when chromatographed as above. The epoxide was not affected by the treatment.

Glucocerebroside was prepared from a Gaucher spleen [11] and labeled with 
tritium in the 6-position of the glucose by a new chemical procedure [12]. Phenylhydrazine-HCl was purified before use [13], dissolved in saline and neutralized with $\mathrm{NaOH}$; final concentration, $1 \mathrm{mg} / \mathrm{ml}$ (as the hydrochloride).

\section{Animals}

Mice (CF-1, Charles River Breeding Labs., 12 days old) were kept in our animal room 4 days, then injected intraperitoneally with either saline or $0.5 \%$ epoxide in saline. Groups of 8 mice, matched for average and variance in body weight, were sacrificed at intervals. The organs were removed, washed in cold saline, blotted with filter paper, weighed individually, and frozen in groups of eight. When each series was finished, the pooled organs were ground with 9 vol. of water in a glass homogenizer and the suspensions were stored in portions at $-20^{\circ} \mathrm{C}$. Just prior to enzyme assay, each portion was freeze-thawed 3 times and diluted with additional water (see Tables I and II).

In the experiment with phenylhydrazine, only male mice were used as they are more sensitive to the hemolyzing agent [14]. The animals (8 per group) were injected with saline or inhibitor and $5 \mathrm{~h}$ later some were killed and the rest were injected with saline or phenylhydrazine in saline. The latter injection was repeated $18 \mathrm{~h}$ later and $8 \mathrm{~h}$ later, for a total of 3 injections (not counting the initial injection of saline or inhibitor). The mice were killed 22, 70, or 118 $\mathrm{h}$ after the last injection and the organs were processes as above. A small portion of blood was drawn by heart puncture before sacrifice, placed in a tube containing EDTA, and the hematocrit determined for each individual animal.

The dosage rate of phenylhydrazine was $40 \mathrm{mg} / \mathrm{kg}$ weight; for the epoxide, it was 100 or $300 \mathrm{mg} / \mathrm{kg}$.

\section{Enzyme assays}

Glucocerebrosidase was assayed by incubating $0.1 \mathrm{ml}$ of tissue homogenate with $0.1 \mathrm{ml}$ of substrate emulsion for $60 \mathrm{~min}$ at $37^{\circ} \mathrm{C}$. The substrate was prepared by evaporating a solution of labeled Gaucher cerebroside $(1.59 \mathrm{mg}$, $\left.9.65 \cdot 10^{5} \mathrm{cpm}\right)$, Cutscum $(0.024 \mathrm{ml})$, and sodium taurocholate $(250 \mathrm{mg})$. To the thoroughly dried residue was added $5 \mathrm{ml}$ of buffer, $\mathrm{pH} 5.4$, made from 0.25 $\mathrm{M}$ citric acid and $0.5 \mathrm{M} \mathrm{K}_{2} \mathrm{HPO}_{4}$. The taurocholate was prepared synthetically [15] and appeared to be quite pure by thin-layer chromatography. After the incubation, the released $\left[{ }^{3} \mathrm{H}\right]$ glucose was isolated by solvent partitioning [16] and counted in $0.3 \mathrm{ml}$ water and $5 \mathrm{ml}$ of scintillation solvent.

Aryl glucosidase (acid glucosidase) was assayed by a slight modification of published procedures $[17,18]$. Each incubation tube contained $0.1 \mathrm{ml}$ of $4 \mathrm{mM}$ methylumbelliferyl- $\beta$-glucoside and $0.05 \%$ Triton X-100 in citrate/phosphate as above ( $1 / 5$ strength). To this was added $0.1 \mathrm{ml}$ of tissue homogenate, diluted with the same buffer to contain 1 or $0.5 \mathrm{mg}$ of tissue. The incubations were stopped after $60 \mathrm{~min}$ by addition of $1.5 \mathrm{ml}$ of $0.2 \mathrm{M}$ sodium-glycine, $\mathrm{pH} 10$.

\section{Results}

\section{Cerebrosidase}

Injection of the inhibitor at 100 or $300 \mathrm{mg} / \mathrm{kg}$ body weight into 16-days old mice produced no significant difference in body or organ weights at time of killing. 

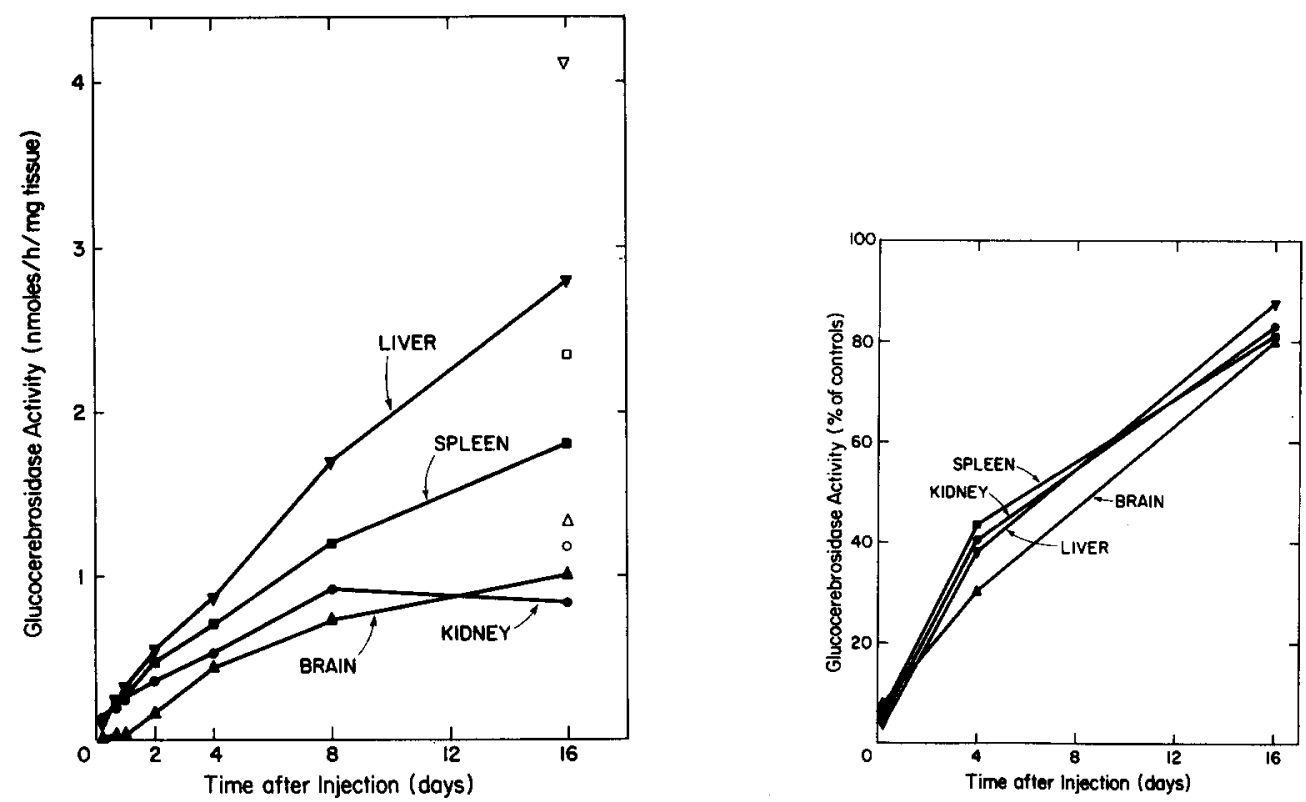

Fig. 1. Specific activity of glucocerebrosidase in tissues of mice injected with conduritol B epoxide, 100 $\mathrm{mg} / \mathrm{kg}$. The open symbols represent mice killed 16 days after injection with saline alone.

Fig. 2. Relative specific activities of tissue cerebrosidase in mice injected with inhibitor, compared with specific activities in control mice killed at each time point. Inhibitor dose: $100 \mathrm{mg} / \mathrm{kg}$.

Glucocerebrosidase levels were almost undetectable in the injected mice when measured $5 \mathrm{~h}$ afterward (Fig. 1). By $17 \mathrm{~h}$ some replacement of the enzyme was detectable except in brain. All the organs showed increasing activities in a simple time pattern except for kidney, which seemed to level off or show a slight decline after 8 days. The enzyme levels were still not back to normal by 16 days (control activities shown there).

A second series of mice was run, with controls killed at each time point (Fig. 2). Again it was evident that full restoration of activity had not been attained by 16 days. The half-lives of the enzymes were calculated $[2,19]$ to be 5.8 days (liver), 7.3 days (kidney), and 8.8 days (spleen and brain).

The enzyme activities in the control mice (Table I) were found to change with age during the 16 day period of study. Brain showed a $22 \%$ decrease between 16 and 32 days of age while liver increased $27 \%$. The former finding is similar to our previous observation with rat brains [20]. The specific activity in liver was somewhat higher than in brain, suggesting that glucolipid and ganglioside metabolism is rapid in liver.

\section{Aryl glucosidase}

Aryl glucosidase was somewhat less effectively inhibited by the epoxide than cerebrosidase (Fig. 3). Brain was particularly insensitive to the inhibitor. It is evident that the two assays measure different enzymes under the conditions used.

Further evidence for the difference in assays came from examination of the 
TABLE I

SPECIFIC ACTIVITY OF $\beta$-GLUCOSIDASES IN CONTROL MICE OF DIFFERENT AGES

Results are expressed as $\mathrm{nmol} / \mathrm{h}$ pex $\mathrm{mg}$ wet tissue. The values for cerebrosidase are derived from incubations with $6 \mathrm{mg}$ each of brain, kidney, and spleen and $4 \mathrm{mg}$ of liver. The activities for aryl glucosidases are derived from $0.5 \mathrm{mg}$ of tissue.

\begin{tabular}{llllllll}
\hline & \multicolumn{2}{l}{ Glucocerebrosidase } & & & \multicolumn{2}{c}{ Aryl glucosidase } \\
\cline { 2 - 3 } \multicolumn{1}{r}{ Age (days): } & 16 & 20 & 32 & & 16 & 20 & 32 \\
\hline Brain & 1.60 & 1.50 & 1.25 & 4.08 & 3.96 & 3.54 \\
Kidney & 1.14 & 1.16 & 1.32 & 1.44 & 1.38 & 1.68 \\
Liver & 3.43 & 3.78 & 4.35 & 2.88 & 3.66 & 4.32 \\
Spleen & 2.01 & 2.05 & 2.34 & 2.70 & 2.40 & 3.00 \\
\hline
\end{tabular}

changes seen with age (Table I). Little change was seen in aryl glucosidase, except for liver, where the specific activity rose $50 \%$ in 16 days. The small decrease in brain had been observed previously in rats [21,22]. A study of aryl glucosidase in human brain revealed no changes between 0 and 40 years [23], but the range of observed specific activities was high.

The effect in brain and liver was examined further, particularly because of reports that rat and mouse brains contain two different aryl $\beta$-glucosidases, differing in their $\mathrm{pH}$ optima and changes with age and scrapie infection [22, 24]. Comparison of the brains and livers from mice killed 1 day after epoxide injection showed a striking difference in the brains (Fig. 4). All of the aryl glucosidase detectable at $\mathrm{pH} 4.1-4.8$ had been destroyed by the inhibitor, but half the activity detectable at $\mathrm{pH} 5.5-5.8$ still remained. Leukocytes from Gaucher patients have also shown a markedly greater decrease in aryl glucosidase activity at low $\mathrm{pH}$, compared with the major enzyme $[25,26]$.
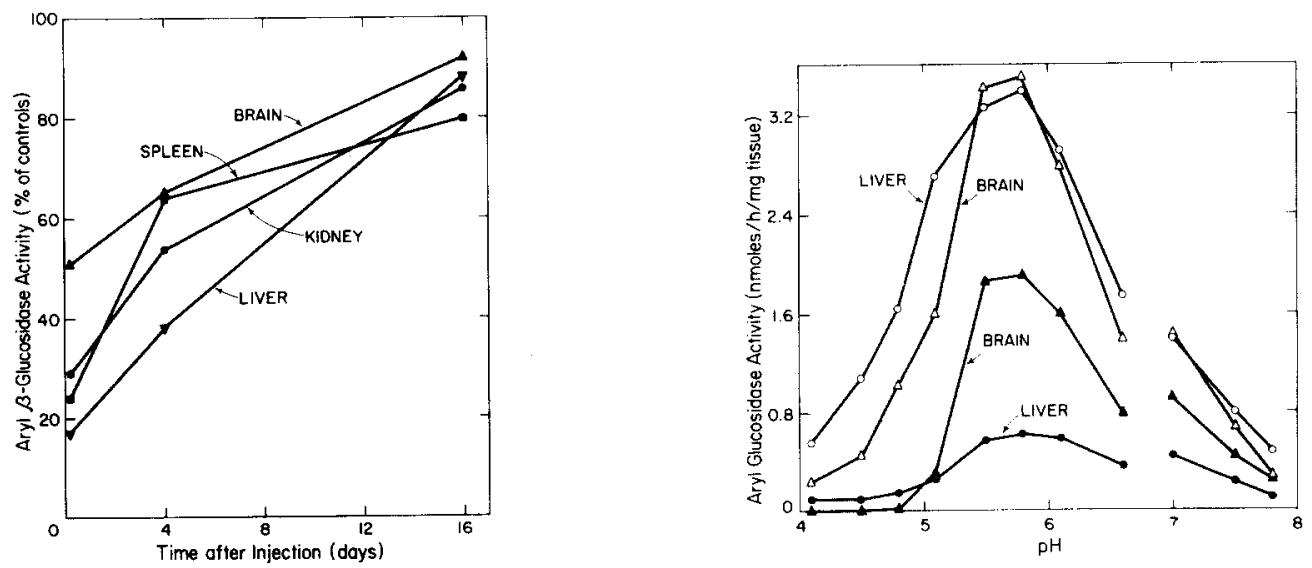

Fig. 3. Relative specific activities of tissue aryl glucosidase in mice injected with inhibitor $(100 \mathrm{mg} / \mathrm{kg})$, compared with activities in controls killed at each time point.

Fig. 4. Effect of $\mathrm{pH}$ on aryl glucosidase in tissues of mice injected with inhibitor (lower two curves) or with saline (upper two curves). The injection was made 1 day prior to sacrifice. Inhibitor dose: $100 \mathrm{mg} /$ kg. The curves on the right were obtained with phosphate buffer lacking citric acid. 
TABLE II

ACTION OF CONDURITOL B EPOXIDE ON ARYL GLUCOSIDASE IN VITRO

The tissues were obtained from 16-days old mice, injected with saline and killed $5 \mathrm{~b}$ later. Each incubation tube contained $1 \mathrm{mg}$ of tissue in $0.1 \mathrm{ml}$ of buffer $\mathrm{pH} 5.4$ and was incubated $1 \mathrm{~h}$ at $37^{\circ} \mathrm{C}$ with or without the inhibitor $(6.2$ or $31 \mathrm{nmol})$. Then $0.1 \mathrm{ml}$ of substrate was added and incubation was continued $1 \mathrm{~h}$ more. Activities are in $\mathrm{nmol} / \mathrm{h}$ per $\mathrm{mg}$ tissue. 1 and 5 denote the amount of conduritol $\mathrm{B}$ epoxide/tube ( $\mu \mathrm{g})$.

\begin{tabular}{|c|c|c|c|c|c|c|c|c|}
\hline & \multicolumn{2}{|c|}{ Brain } & \multicolumn{2}{|c|}{ Kidney } & \multicolumn{2}{|c|}{ Liver } & \multicolumn{2}{|c|}{ Spleen } \\
\hline & 1 & 5 & 1 & 5 & 1 & 5 & 1 & $\mathbf{5}$ \\
\hline Activity in controls & \multicolumn{2}{|c|}{3.2} & \multicolumn{2}{|c|}{1.1} & \multicolumn{2}{|c|}{1.4} & \multicolumn{2}{|c|}{2.0} \\
\hline $\begin{array}{l}\text { Inhibition by conduritol B epoxide } \\
\text { (\% of controls) }\end{array}$ & 47 & 75 & 37 & 85 & 65 & 87 & 54 & 91 \\
\hline
\end{tabular}

Injection of higher doses of epoxide $(300 \mathrm{mg} / \mathrm{kg})$ did result in greater destruction of aryl glucosidase activity, but there was still an appreciable amount of residual activity after $\mathbf{5} \mathrm{h}$. It seemed possible that this assay reflects, in part, the activity of a $\beta$-glucosidase that is insensitive to the inhibitor. This possibility was investigated by incubating tissue homogenates for $1 \mathrm{~h}$ in vitro with epoxide, then assaying for aryl glucosidase (Table II). At the higher concentration used $(0.31 \mathrm{mM})$, enzyme destruction was still incomplete, although more complete than in the in vivo experiments. In this experiment, as in the in vivo experiment, the aryl glucosidase in brain was less affected than in the other organs. Using shorter time periods [27], we found that cerebrosidase activity in liver and brain was destroyed within $2 \mathrm{~h}$. Thus, only part of the residual activity seen in these mice could be due to inadequate penetration of the tissues by the inhibitor; it seems most likely that the assay measures, in part, a glucosidase that is rather insensitive to the epoxide, and that brain contains a somewhat higher proportion of this enzyme.

\section{Phenylhydrazine effects}

The animals injected with phenylhydrazine reacted in the expected way (Table III). Hemolysis resulted in a low hematocrit value within 2 days after the first phenylhydrazine injection and partial recovery on the sixth day. Also expected was the increase in spleen weight, which was significantly increased on the sixth day. The kidneys showed the previously noted quick decrease in glucosidase activities in conduritol B epoxide-treated mice, followed by a partial recovery within 6 days. However, the effects of phenylhydrazine in that organ were very small, as would be expected since the kidney is not known to play a role in blood cell metabolism.

Both liver and spleen responded to the phenylhydrazine injection with a marked increase in specific activity of cerebrosidase (Fig. 5). The increase was seen in both the control animals and those injected with conduritol B epoxide. During the first 2 days, the phenylhydrazine effect was slight in the conduritol B epoxide-treated mice, but between 2 and 4 days the conduritol B epoxidetreated mice showed a much greater increase than the control mice in cerebrosidase activity in response to the hemolytic stress. In the liver, the specific activity rose by 1.3 units ( $\mathrm{nmol} / \mathrm{h}$ per $\mathrm{mg}$ tissue) in the control animals while 


\section{T ABLE III}

CHANGES IN SPLEEN WEIGHT AND HEMATOCRIT VALUES IN MICE INJECTED WITH CONDURITOL B EPOXIDE AND PHENYLHYDRAZINE

Numbers in parentheses are standard deviations. $\mathrm{CBE}=$ conduritol $\mathrm{B}$ epoxide, $\mathrm{PHZ}=$ phenylhydrazine.

\begin{tabular}{|c|c|c|c|c|}
\hline Mouse group & Saline/saline & $\mathrm{CBE} /$ saline & Saline/PHZ & $\mathrm{CBE} / \mathrm{PHZ}$ \\
\hline \multicolumn{5}{|c|}{ Spleen weight (mg) } \\
\hline 16 days old & $14(7)$ & 15 (9) & - & - \\
\hline 18 days old & $20(11)$ & 15 (6) & $28(24)$ & $21(14)$ \\
\hline 22 days old & $54(36) *$ & $34(29) * *$ & $158(73)^{*}$ & $125(70) * *$ \\
\hline \multicolumn{5}{|c|}{ Hematocrit $(\times 100)$} \\
\hline 16 days old & $37 \quad(2)$ & $35 \quad(3)$ & - & - \\
\hline 18 days old & $37 \quad$ (3) *** & $37 \quad(4) * *$ & $26 \quad(4) * * *$ & $27 \quad(5) * *$ \\
\hline 22 days old & 38 (3)* & $34 \quad(2)$ & $30(6) *$ & $30(7)$ \\
\hline
\end{tabular}

* Significantly different at the $P<0.02$ level.

** Significantly different at the $P<0.01$ level.

*** Significantly different at the $P<0.001$ level.

it rose by 2.6 units in the enzyme-depleted animals. The change in spleen was similar in magnitude. Between the 4th and 6th days, the accelerating effect of conduritol B epoxide was still visible in the liver, but undetectable in spleen.

The magnitude of the phenylhydrazine effect is shown more clearly in the case of spleen when the cerebrosidase activities are calculated for the entire spleen instead of the specific activity (Fig. 6). The specific activities are distorted by the enlargement of the spleen due to accumulation of hemolyzed cells which, we found in a separate study, contain very low levels of glucocerebrosidase. Analyzed this way, it is seen that the normal spleens after conduritol $B$ epoxide treatment reached the control level within 4 days and that hemolysis produced greatly enhanced levels of cerebrosidase.

As with cerebrosidase, the phenylhydrazine treatment produced a rapid increase in aryl glucosidase levels, the effect appearing particularly fast (even

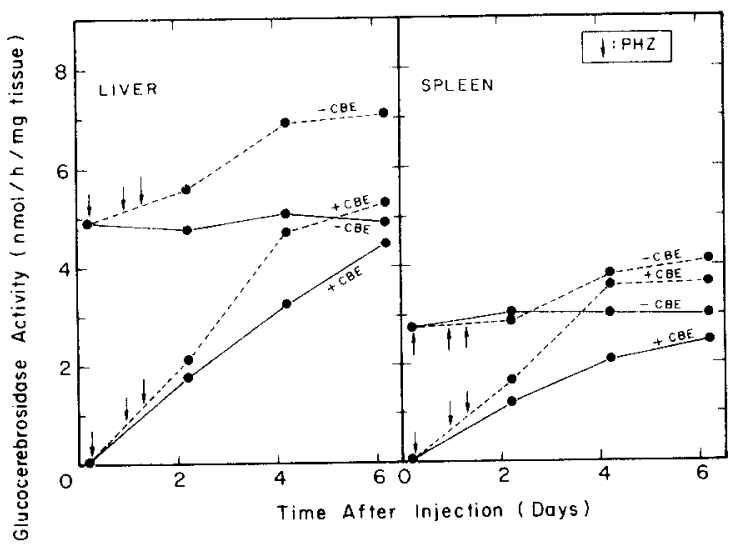

Fig. 5. Glucocerebrosidase specific activities in mice injected at zero time with saline or with conduritol $B$ epoxide (CBE). At the times marked by arrows, phenylhydrazine solution was injected into half the mice in each. Conduritol B epoxide dose: $300 \mathrm{mg} / \mathrm{kg}$. 

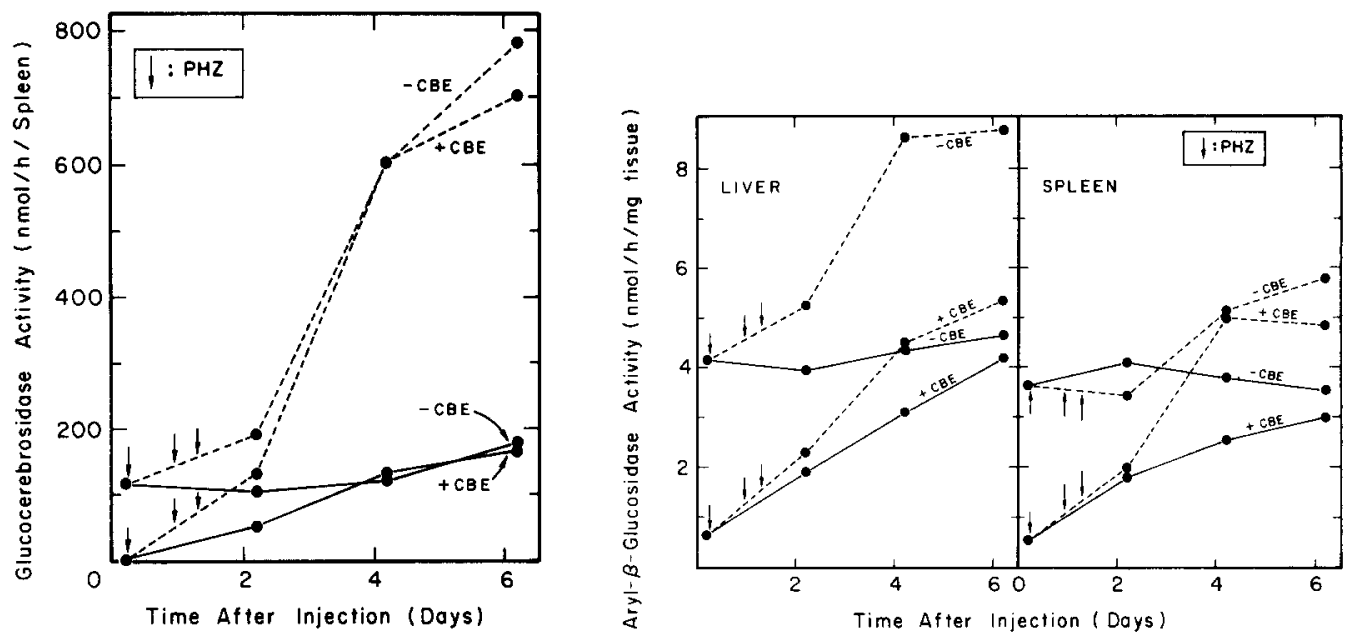

Fig. 6. Total cerebrosidase activity per spleen in mice injected as in Fig. 5 (see legend for explanation of symbols).

Fig. 7. Specific activity of aryl glucosidase in mice injected with saline, conduritol B epoxide, or phenylhydrazine. See legend to Fig. 5 for explanation.

within 2 days in the case of liver). In the case of liver, the increase between 2 and 4 days was greater in the animals not injected with conduritol B epoxide; this contrasts with the increases seen in cerebrosidase. However, the increase in spleen was greater between 2 and 4 days in the conduritol B epoxide-treated mice. Outside of this difference, the overall pattern of changes was rather similar for cerebrosidase and aryl glucosidase (Fig. 5 vs. Fig. 7).

The dose of conduritol B epoxide was somewhat greater in the phenylhydrazine study than in the enzyme reappearance study (Fig. 3). This explains the somewhat greater disappearance of aryl glucosidase right after conduritol $B$ epoxide injection.

To eliminate the possibility that phenylhydrazine treatment somehow produced a stimulating agent that enhanced glucocerebrosidase activity in the assay system, we incubated homogenates of control spleen $(3 \mathrm{mg})$, phenylhydrazine spleen $(3 \mathrm{mg})$, and a mixture of both $(1.5 \mathrm{mg}$ each). There was only the expected average value obtained with the mixture. The same results were found with liver.

Another test was carried out by incubating $2 \mathrm{mg}$ of normal liver in citrate/

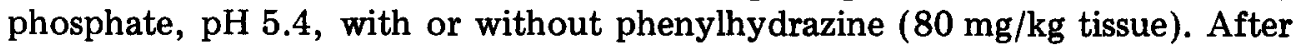
$1 \mathrm{~h}$ at $37^{\circ} \mathrm{C}$, we added the glucocerebroside emulsion and incubated an additional hour. No effect of the toxin on the enzyme could be detected.

\section{Discussion}

The technique of measuring enzyme turnover by rapid destruction of the enzyme and measurement of its reappearance is convenient but its validity for any given enzyme requires independent confirmation by another technique. It assumes that reappearance of activity is not due to reactivation of the enzyme. 
In the case of glucosidases, which appear to undergo reaction with conduritol $B$ epoxide to form an ester with aspartic acid at the active site [4], reactivation would require either spontaneous or enzymatic hydrolysis of the ester linkage. If such reactivation occurred in our mice, the rate of enzyme synthesis must be even slower than the calculated rate. However, our observed values of approx. 6-9 days for cerebrosidase are similar to values seen for a number of other enzymes.

Another assumption one must make for this technique is that the inhibitor disappears from the body relatively quickly, so that the synthesis of new enzyme molecules can become visible in a reasonable time. Conduritol B epoxide is a very small, non-ionic, water-soluble molecule that very likely undergoes rapid excretion or hydrolysis. In separate experiments, reported in the accompanying paper [27], we found some reappearance of glucosidase activity in liver within $5 \mathrm{~h}$ after injection of conduritol B epoxide, so this inhibitor fulfills that requirement. Reappearance of cerebrosidase in brain was slower, which could mean there is greater retention of the compound in that organ.

Another possible complication of the inhibition-resynthesis approach is that loss of enzyme might stimulate the rate of synthesis through some feedback mechanism. However, such an effect would presumably produce an S-shaped recovery curve rather than the simple curves we found.

A curious shift in the turnover rates of the glucosidases with age of the mouse colony deserves comment. The data shown in Figs. 1-3 were obtained early in this study. This was followed by a study with phenylhydrazine, not shown in this paper (although the findings were quite similar), and estimating the turnover rates for the control animals, injected only with saline or conduritol $B$ epoxide, yielded half-lives for both enzymes of $6-9$ days. The values agreed reasonably well with the first series. However, the data shown in Figs. 5 and 7 clearly show higher turnover rates, as well as higher specific activities. The half-lives for cerebrosidase were 1.5 and 2.4 days for liver and spleen; for aryl glucosidase the corresponding values were 2.7 and 3.4 days. The differences cannot be attributed to changes in the animals with time of year, since the phenylhydrazine studies were run 13 months apart. However, the early work was done with animals from a recently established animal colony and the later work, with the same but matured colony. This could mean that glucosidases are sensitive to environmental factors. Some support for this interpretation comes from work in this laboratory (Penar, P.L. and Radin, N.S., unpublished) demonstrating that liver cerebrosidase follows a distinct diurnal rhythm. The high point (at $6: 00$ P.M.) was about $32 \%$ higher than the low point (at 6 : 00 A.M.).

Interpretation of the experiments with phenylhydrazine can be made by assuming that the level of an enzyme depends on its rate of synthesis and its rate of proteolytic degradation. Loading the liver and spleen with decomposing erythrocytes could overload the proteolytic enzymes that normally digest glucosidases. This explanation is improbable because Kampine et al. [7] found no effect on glucosidases or other hydrolases when they injected their rats with lipid-free erythrocyte stroma, yet the glucosidase levels rose when they injected unextracted stroma. Another effect of the hemolysis could be an overload of 
glucolipids from the cell membranes, which would increase the proportion of cerebrosidase bound to its substrate; this enzyme-substrate complex could be resistant to proteolytic digestion. Both protective effects would result in an increased level of cerebrosidase. In the case of the conduritol B epoxide-treated mice, where very little glucosidase was present even in the non-hemolyzed animals, one would expect that such effects would be minor and the observed increase in the rate of enzyme reappearance may reflect primarily an enhanced rate of enzyme synthesis.

The rate of cerebrosidase increase between days 2 and 4 was doubled in mice subjected to hemolysis (compare the broken lines in Fig. 5). This could signify that the mice lacking cerebrosidase responded more effectively to the factor causing increased synthesis of the enzyme. When one compares the increases in cerebrosidase specific activity occurring in liver during the initial period, $0-2$ days, one sees that hemolysis produced a greater rise in the normal animals $(5.57-4.77=0.8$ units) than in the conduritol $\mathrm{B}$ epoxide-treated animals $(2.12-1.78=0.34$ units $)$. This could mean that the major factor producing a rise in enzyme activity during this period is reduction in enzyme proteolysis.

The rise in cerebrosidase and aryl glucosidase that we found after phenylhydrazine treatment was reported previously in rat spleens after similar treatment [7]. Our experiment extended the finding to liver, in which the response was even greater than in spleen. Perhaps liver plays a greater role than spleen in the destruction of hemolyzed (and normal?) blood cells.

Comparison of our data for aryl glucosidase and cerebrosidase (Figs. 5 and 7) shows that the changes were qualitatively similar, but that hemolysis induced a greater increase in normal liver and spleen for the former enzyme. While it is generally thought that glucose occurs only in the lipids of erythrocytes, so the response to hemolysis should be only in cerebrosidase, there is a report of a glucosylated peptide in erythrocytes [28] and this might be a substrate for aryl glucosidase. It is thus possible that aryl glucosidase production is induced to handle the increased load of this or similar protein-bound glucoside.

A study of aryl glucosidase in mouse liver and brain, after prolonged conduritol $\mathrm{B}$ epoxide administration, which appeared while this paper was under review [29], yielded similar values for the half-lives.

\section{Acknowledgements}

Part of the conduritol B was synthesized by Drs. Norman Boyd and Ranga Vunnam in this laboratory. We are indebted to Dan del Vecchio and Inez Mason for laboratory assistance and to the U.S. Public Health Service for grants NS-03192 and HD-07406.

\section{References}

1 Price, V.E., Sterling, W.R., Tarantola, V.A., Hartley, R.W., Jr. and Rechcigl, M., Jr. (1962) J. Biol. Chem. 237, 3468-3475

2 Davis, G.A. and Agranoff, B.W. (1968) Nature 220, 277-280

3 Legler, G. (1966) Z. Physiol. Chem. 345, 197-214

4 Legler, G. (1970) Z. Physiol. Chem. 351, 25-31

5 Kanfer, J.N., Raghaven, S.S., Mumford, R.A., Sullivan, J., Spielvogel, C., Legler, G., Labow, R.S., Wil- 
liamson, D.G. and Layne, D.S. (1976) Current Trends in Sphingolipidoses and Allied Disorders, (Volk, B.W. and Schneck, L., eds.), pp. 77-98, Plenum Press, New York

6 Kanfer, J.N., Legler, G., Sullivan, J., Raghavan, S.S. and Mumford, R.A. (1975) Biochem. Biophys. Res. Commun. 67, 85-90

7 Kampine, J.P., Kanfer, J.N., Gal, A.E., Bradley, R.M. and Brady, R.O. (1967) Biochim. Biophys. Acta $137,135-139$

8 Hara, A, and Radin, N.S. (1977) Fed. Proc. 36, 731

9 Nagabhushan, T.L. (1970) Can. J. Chem. 48, 383-384

10 Oesch, F., Jerina, D.M. and Daly, J. (1971) Biochim. Biophys. Acta 227, 685-691

11 Radin, N.S. (1976) J. Lipid Res. 17, 290-293

12 McMaster, M.C., Jr. and Radin, N.S. (1977) J, Labeled Compd. Radiopharm. 13, 353-357

13 Vogel, A.I. (1956) Practical Organic Chemistry, 3rd edn., p. 637, Longmans, Green and Co., London

14 Toth, B., Shimizu, H., Sornson, H., Issenberg, P. and Erickson, J. (1975) Res. Commun. Chem. Pathol. Pharmacol. 10, 577-580

15 Norman, A. (1955) Ark. Kemi 8, 331-342

16 Radin, N.S. and Arora, R.C. (1971) J. Lipid Res. 12, 256-257

17 Ho, M.W., O'Brien, J.S., Radin, N.S. and Erickson, J.S. (1973) Biochem. J. 131, 173-176

18 Ho, M.W., Seck, J., Schmidt, D., Veath, M.L., Johnson, W., Brady, R.O. and O'Brien, J.S. (1972) Am. J. Hum. Genet. 24, 37-45

19 Rechcigl, M., Jr. and Heston, W.E. (1967) Biochem. Biophys. Res. Commun, 27, 119-124

20 Radin, N.S., Hof, L., Bradley, R.M. and Brady, R.O. (1969) Brain Res. 14, 497-505

21 Bowen, D.M. and Radin, N.S. (1969) J. Neurochem. 16, 501-511

22 Hermans, I.J., Hoving, H. and Hooghwinkel, G.J.M. (1973) Neurobiol. 3, 45-51

23 Harzer, K, and Sandhoff, K. (1971) J. Neurochem. 18, 2041-2050

24 Millson, G.C. and Bountiff, L. (1973) J. Neurochem. 20, 541-546

25 Beutler, E. and Kuhl, W. (1970) J. Lab. Clin. Med. 76, 747-755

26 Turner, B.M., Beratis, N.G. and Hirschhorn, K. (1977) Biochim. Biophys. Acta 480, 442-449

27 Hara, A. and Radin, N.S. (1979) Biochim. Biophys. Acta 582, 423-433

28 Weiss, J.B., Lote, C.J. and Bobinski, H. (1971) Nat. New Biol. 234, 25-26

29 Stephens, M.C., Bernatsky, A., Burachinsky, V., Legler, G. and Kanfer, J.N. (1978) J. Neurochem. 30, 1023-1027 